\title{
Evaporation from Camargos hydropower plant reservoir: water footprint characterization
}

\section{Evaporação do reservatório da usina hidrelétrica de Camargos: caracterização da pegada hídrica}

\author{
Eduardo de Oliveira Bueno ${ }^{1}$, Carlos Rogério de Mello ${ }^{1}$ and Geovane Junqueira Alves ${ }^{1}$ \\ ${ }^{1}$ Universidade Federal de Lavras, Lavras, MG, Brazil \\ E-mails: eobueno@yahoo.com.br (EOB), crmello@deg.ufla.br (CRM), geovane@agricola.eng.br (GJA)
}

Received: February 05, 2016 - Revised: April 04, 2016 - Accepted: April 13, 2016

\begin{abstract}
In recent years, a relevant debate has been raised by a question related to if the hydropower plants indeed represent a non-consumptive use of water resources. In this context, this work was developed at the Camargos Hydropower Plant reservoir, Grande river basin, southern Minas Gerais state, aiming to estimate evaporation rates, which allow the characterization of the Water Footprint in this facility, between the years of 2010 and 2014. Evaporation rates were estimated based on Linacre, Penman and Penman-Monteith methods. Regarding the distribution of evaporation throughout the year, all methods showed the same seasonal pattern, consistent with the meteorological elements behavior that influence this physical process. Although an annual average evaporation considered normal for the studied region $(1329 \mathrm{~mm})$ and a small reservoir area $\left(64 \mathrm{~km}^{2}\right)$, this hydropower plant has presented low electric energy production as it is an old facility (more than 50 years) and has low installed capacity. Therefore, Camargos Hydropower Plant has presented, by all methods, a high Water Footprint $\left(130 \mathrm{~m}^{3} . \mathrm{GJ}^{-1}\right.$ on average) compared to estimates for other hydropower plants in Brazil and worldwide.
\end{abstract}

Keywords: Evaporation; Hydroelectric; Water footprint.

\section{RESUMO}

Nos últimos anos, um debate relevante tem ocorrido provocado pelo questionamento se as usinas hidrelétricas são de fato de uso não consuntivo dos recursos hídricos. Neste contexto, foi desenvolvido um estudo no reservatório da usina hidrelétrica de Camargos, rio Grande - Minas Gerais, com o objetivo de estimar as taxas de evaporação e caracterizar a pegada hídrica desta usina para o período de 2010 a 2014. A evaporação foi estimada pelos métodos de Linacre, Penman e Penman-Monteith. Em relação à distribuição da evaporação ao longo do ano, todos os métodos apresentaram o mesmo padrão sazonal, condizente com o comportamento das variáveis meteorológicas que influenciam o processo. Apesar de uma evaporação anual média $\left(1329 \mathrm{~mm}\right.$.ano $\left.{ }^{-1}\right)$ e da pequena área do reservatório $\left(64 \mathrm{~km}^{2}\right)$, por se tratar de um aproveitamento antigo (mais de 50 anos) e com baixa potência instalada, a geração da usina hidrelétrica de Camargos é pequena, resultando, para todos os métodos avaliados, em uma pegada hídrica elevada (média de $130 \mathrm{~m}^{3} . \mathrm{GJ}^{-1}$ ), comparada as estimativas indicadas na literatura para outras usinas hidrelétricas no Brasil e no mundo.

Palavras-chave: Evaporação; Hidrelétrica; Pegada hídrica. 


\section{INTRODUCTION}

In recent years, due to the increase scarcity of water resources, an important debate has been triggered by questioning whether the use of water resources by hydroelectric plants is in fact non-consumptive. This issue has been linked to the concept of water footprint (WFP), which is defined as the total volume of water used directly or indirectly in the production of a unit of goods and services (HOEKSTRA et al., 2011).

For hydroelectric generation, WFP quantification can be carried out based on the relationship between evaporation from reservoirs and electric energy produced in a given period, since the higher the WFP the lower the water resource use efficiency.

The hydropower water footprint is function of evaporation from the reservoirs, which means the higher this process the larger the water footprint. Therefore, it depends on the size (surface area) of the reservoir and climatic conditions (especially solar radiation, wind velocity and air temperature) that directly influence evaporation. On the other hand, WFP is inversely related to the electric energy production by the facilities, that is, the lesser the energy produced, the larger the water footprint. Thus, there is a direct dependency of installed capacity, turbine efficiency and market demand.

In this context, we developed a WFP study for the Camargos Hydropower Plant (HPP), which is the most upstream facility located in the Upper Grande river basin, southern Minas Gerais state, using meteorological data obtained directly from the site as well as Camargos operational data for a period of five years (2010-2014).

The aim was to estimate evaporation rates using different meteorological methods and characterize the WFP of the Camargos
HPP, based on the electric energy production, comparing the results against those indicated for other plants in Brazil and in the world.

\section{MATERIAL AND METHODS}

\section{Study area characterization}

The study area involves Camargos HPP reservoir, whose dam has 37 meters high and is located in the Grande River at the coordinates of $21^{\circ} 20^{\prime} \mathrm{S}$ and $44^{\circ} 37^{\prime} \mathrm{W}$ in the municipality of Itutinga, Minas Gerais state, Brazil. It is important to highlight that Grande river basin is one the most important Brazilian basin for electric energy production, encompassing 14 facilities throughout the river (VIOLA et al., 2014).

The climate of the region, according to Köppen classification, is Cwa, which means a temperate climate, with mild and humid summers and cold and dry winters, with mean annual rainfall of $1500 \mathrm{~mm}$ (MELLO et al., 2012).

In addition, Camargos HPP reservoir is the most upstream project on the Grande river basin (Figure 1), with a contributing area of $6228 \mathrm{~km}^{2}$. Its reservoir has a useful volume of $792 \mathrm{hm}^{3}$, with normal water operating level at an elevation of $910 \mathrm{~m}$, an average depth of $8 \mathrm{~m}$ and normal water surface of $64 \mathrm{~km}^{2}$.

\section{Electric power generation data from Camargos HPP}

The Camargos HPP has an installed capacity of $46 \mathrm{MW}$, however, since it is a plant with more than 50 years of operation, its current capacity is low. The average power generation in the studied period (2010 to 2014) was 19 MW,

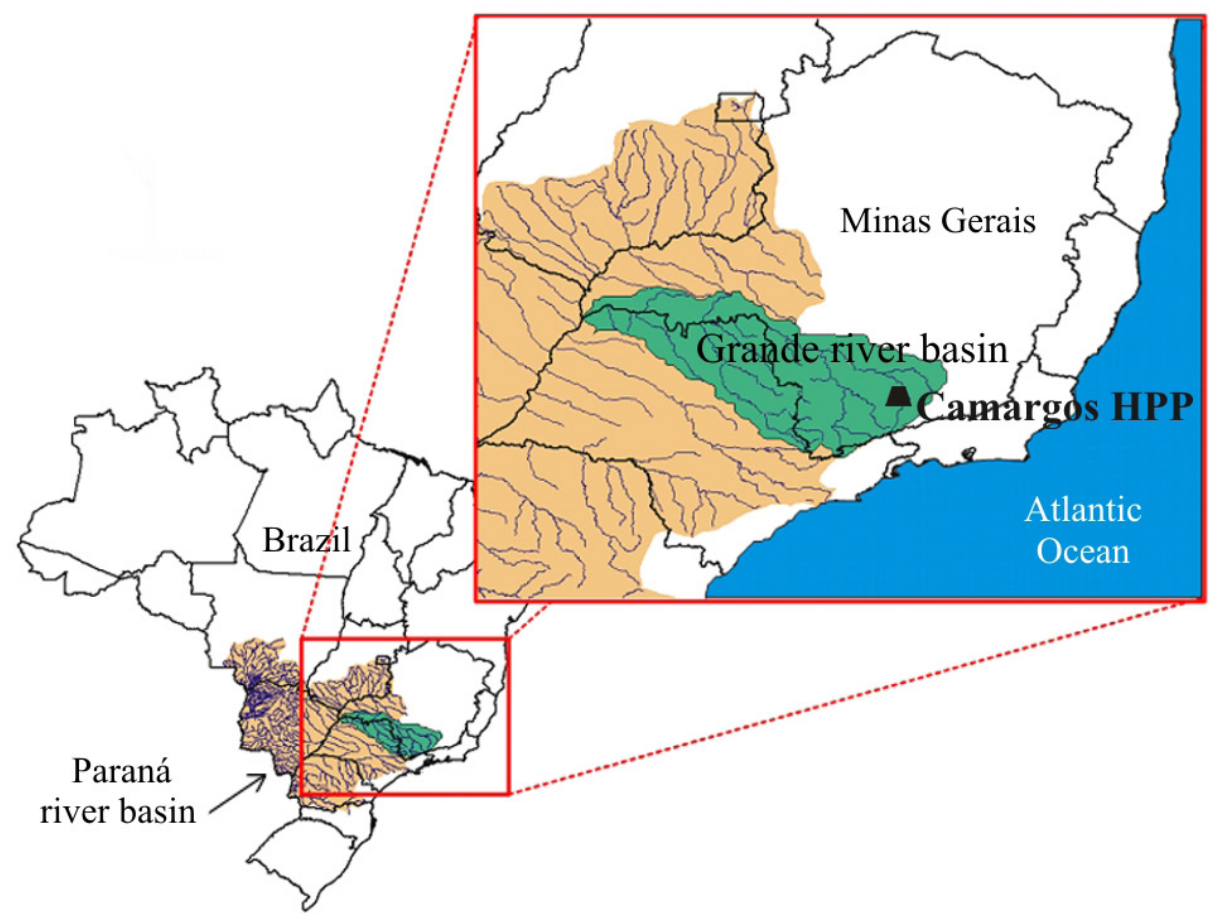

Figure 1. Location of Camargos HPP. Adapted from FINEP (2007). 
which was influenced by the historical drought that affected the region in 2014, implicating in a generation only about $6 \mathrm{MW}$ for this year. Regarding the monthly distribution of the electric energy production, Camargos HPP has increased its production capacity from mid-November, taking the peak in January and then, decreasing gradually until reaching a minimum in the first half of November. This behavior is mainly linked to the market demand.

\section{Meteorological data}

The meteorological data used in this study were obtained by a Campbell weather station, called "Marcela", located approximately $6 \mathrm{~km}$ to the north of Camargos HPP reservoir, at geographic coordinates $21^{\circ} 16^{\prime} \mathrm{S}$ and $44^{\circ} 30^{\prime} \mathrm{W}$ and at $979 \mathrm{~m}$ of altitude. The meteorological elements were automatically monitored every $30 \mathrm{~min}$, storing the data on temperature and relative humidity, wind speed, solar radiation, and atmospheric pressure.

Table 1 shows the monthly average values for the period 2010-2014, when the average air temperature was $19.2^{\circ} \mathrm{C}$, relative humidity $71.6 \%$, wind speed $2.8 \mathrm{~m} \cdot \mathrm{s}^{-1}$ and the income solar radiation of $14.5 \mathrm{MJ} \cdot \mathrm{m}^{-2}$.day ${ }^{-1}$.

In 2014, air temperature, wind speed and solar radiation were higher than the average from the previous years (2010 to 2013), whereas the relative humidity was the lowest of the studied period. This weather is associated with the historical drought that affect the southeastern Brazil in the 2014, explained by the intensification of South Atlantic Subtropical Anticyclone, with reduction of the occurrence of South Atlantic Convergence Zone (SACZ) episodes over southeastern Brazil (COELHO; CARDOSO; FIRPO, 2015).

\section{Water footprint calculation method}

The calculation of the water footprint for Camargos HPP was carried out annually based on the total evaporated estimated by the studied methods, and the total electric energy produced by the cited plant.
For Mekonnen and Hoekstra (2012), the water footprint (WFP), in $\mathrm{m}^{3} . \mathrm{GJ}^{-1}$, for hydroelectric generation can be obtained by the following expression:

$$
W F P=\frac{E}{H}
$$

Where $\mathrm{E}$ and $\mathrm{H}$ are, respectively, the annual evaporation $\left(\mathrm{m}^{3}\right)$ and electric energy production (GJ).

In addition to the annual estimate, the seasonal behavior of the WFP was also analyzed, verifying the months of the year in which it is more critical, since this depends on both weather conditions and market demand for electricity. To calculate the monthly water footprint, we considered the monthly average surface area (A) of the Camargos HPP reservoir, which ranged from $50 \mathrm{~km}^{2}$ (in December) to $65 \mathrm{~km}^{2}$ (in May), obtained based on daily water level readings $(\mathrm{L})$ and the $\mathrm{L} \times \mathrm{A}$ reservoir curve.

According to Mekonnen and Hoekstra (2012), the volume of water used to calculate WFP is estimated based on only the evaporation from reservoirs, which means disregarding the consumption of water for operation of the plant (equipment cooling, washing of machines, use by employees and others), admitting that these are insignificant if compared to the volume evaporated from reservoir.

\section{Methodologies adopted for evaporation estimation}

Direct estimates of evaporation from reservoirs, in adequate both spatial and temporal scales, requires sophisticated and expensive devices, like those based on turbulent vortices ("Eddy Covariance"). Thus, theoretical methods, which are based on physical principles of evaporation and take into account weather elements, are mostly used as a plausible alternative.

Evaporation from Camargos HPP reservoir for the period between 2010 and 2014 was estimated by the methods listed in Table 2 with respective source.

It is important to highlight that we did not applied water budget technique to estimate evaporation from Camargos HPP reservoir due to errors identified in some of the variables which are inputs for this procedure, especially the inflows and outflows.

Table 1. Mean values (2010-2014) of the meteorological elements observed by "Marcela" weather station.

\begin{tabular}{|c|c|c|c|c|c|}
\hline Month & $\begin{array}{l}\text { Air temperature } \\
\left({ }^{\circ} \mathrm{C}\right)\end{array}$ & $\begin{array}{l}\text { Relative humidity } \\
\qquad(\%)\end{array}$ & $\begin{array}{l}\text { Wind speed } \\
\qquad\left(\mathrm{m} \cdot \mathrm{s}^{-1}\right)\end{array}$ & $\begin{array}{c}\text { Atmospheric } \\
\text { pressure } \\
(\mathrm{hPa})\end{array}$ & $\begin{array}{c}\text { Overall solar } \\
\text { radiation } \\
\left(\mathrm{MJ} \cdot \mathrm{m}^{-2} \cdot \mathrm{day}^{-1}\right)\end{array}$ \\
\hline January & 21.6 & 78.0 & 2.3 & 901.2 & 16.1 \\
\hline February & 22.5 & 69.1 & 2.1 & 901.5 & 19.5 \\
\hline March & 21.0 & 78.3 & 2.6 & 901.6 & 14.3 \\
\hline April & 19.7 & 77.2 & 2.1 & 903.1 & 13.4 \\
\hline May & 16.5 & 79.5 & 2.1 & 904.3 & 10.9 \\
\hline June & 15.2 & 79.6 & 1.9 & 905.6 & 10.3 \\
\hline July & 15.5 & 73.2 & 1.9 & 905.4 & 11.7 \\
\hline August & 16.9 & 64.7 & 2.7 & 905.3 & 14.2 \\
\hline September & 19.1 & 58.4 & 3.0 & 903.3 & 16.5 \\
\hline October & 20.3 & 68.5 & 3.3 & 900.6 & 15.4 \\
\hline November & 20.0 & 74.1 & 3.0 & 899.7 & 15.1 \\
\hline December & 21.9 & 75.1 & 2.0 & 898.9 & 16.7 \\
\hline
\end{tabular}




\section{RESULTS AND DISCUSSION}

\section{Evaporation from Camargos HPP reservoir between 2010 and 2014}

Figure 2 shows the monthly Camargos HPP reservoir evaporation estimated based on the methods listed in Table 2.

At this time scale, all methods showed the same seasonal evaporation pattern, with minimum daily rates estimated for June, which presented the lowest values of both air temperature and solar radiation. Maximum rate values were calculated for the months from December to February, which are characterized by the highest air temperature and solar radiation

Table 3 presents the mean monthly evaporation values for Camargos HPP reservoir, estimated by the methods of Linacre, Penman and Penman-Monteith, which require local weather observations, and adopted by ONS (National Electric System Operator), which uses only average weather elements from Climatological Normal from 1961-1990 of the INMET stations for the location of interest (ANDRIOLO; KAVISKI, 2005).

The evaporation distribution throughout the year showed quite similar pattern among the cited methods and is directly related to the seasonal weather elements that strongly influence the process. The highest rates were estimated for the period from September to March (when normally the highest of both solar radiation and air temperature values are observed in the region) and for October due to stronger winds that are normally observed in southern Minas Gerais state.

Table 4 presents the annual evaporation from Camargos HPP reservoir for the years between 2010 and 2014, obtained by the studied methods, comparing against ONS method (ONS, 2004). The mean annual evaporation, calculating based on the studied methods, was equivalent to $1329 \mathrm{~mm} \cdot \mathrm{yr}^{-1}$, which is greater than the potential evapotranspiration for the region (950 mm.year ${ }^{-1}$ ), according to Viola et al. (2015).

The annual evaporation in 2014 was the highest, regardless of the meteorological method applied, except for ONS as it uses long-term averages from Climatological Normal. This result occurred as the meteorological methods taken into account the meteorological elements observed in situ ("Marcela" station), and these are associated to the anomalous climate period observed in the region (and in southeastern Brazil as a whole), which has been classified as the worst drought period ever recorded in the region (COELHO; CARDOSO; FIRPO, 2015).

In 2014, average air temperature, wind speed and solar radiation were much higher than the average of the previous years

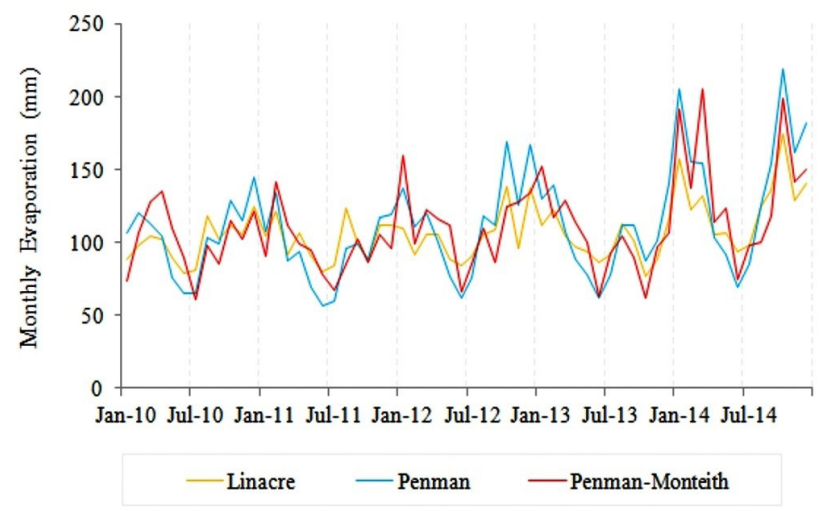

Figure 2. Monthly evaporation from Camargos HPP reservoir for the period between 2010 and 2014.

Table 2. Equations for evaporation estimation from reservoirs and their most relevant features.

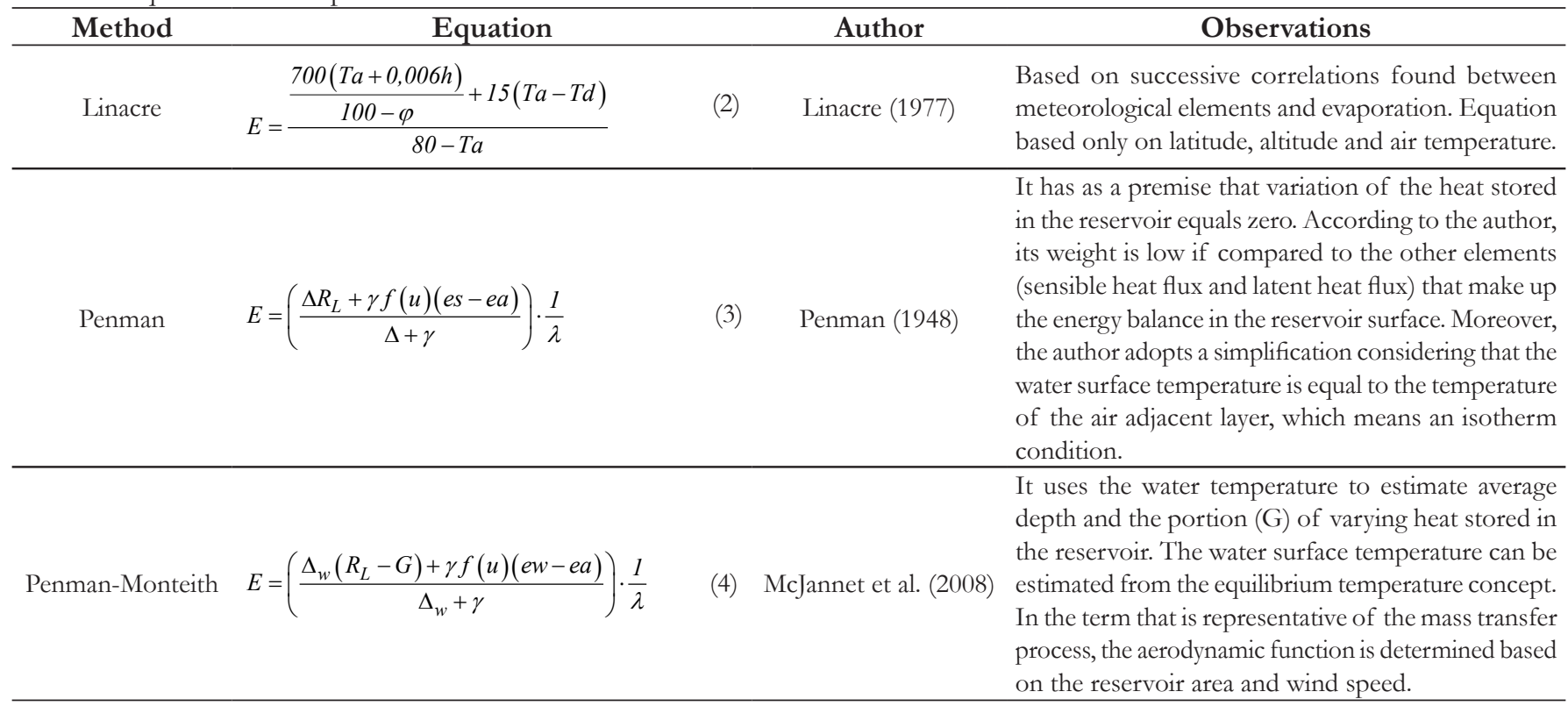

Where: E - evaporation $\left(\mathrm{mm}_{\text {day }}{ }^{-1}\right) ; \mathrm{Ta}$ - average air temperature $\left({ }^{\circ} \mathrm{C}\right) ; \mathrm{h}$ - elevation $(\mathrm{m}.) ; \varphi$ - latitude (decimal degrees); Td - dew point temperature $\left({ }^{\circ} \mathrm{C}\right) ; \lambda-$ latent heat of vaporization $\left(\mathrm{MJ} \cdot \mathrm{kg}^{-1}\right) ; \Delta-$ slope of the saturation pressure curve of water vapor in the air at the air temperature $\left(\mathrm{kPa}^{\circ} \mathrm{C}^{-1}\right) ; \mathrm{R}_{\mathrm{L}}-$ net radiation $\left(\mathrm{MJ} \cdot \mathrm{m}^{-2}\right.$. day $\left.{ }^{-1}\right)$; $\mathrm{f}(\mathrm{u})$ - aerodynamic function $\left(\mathrm{MJ} \cdot \mathrm{m}^{-2} \cdot \mathrm{day}^{-1} \cdot \mathrm{kPa}^{-1}\right)$; es - saturation pressure of vapor water in the air at the air temperature $(\mathrm{kPa})$; ea - the partial pressure of water vapor in the air at the air temperature $(\mathrm{kPa}) ; \gamma$ - psychometric constant $\left(\mathrm{kPa} .{ }^{\circ} \mathrm{C}^{-1}\right) ; \Delta \mathrm{w}$ - slope of the saturation pressure curve of water vapor in the air at the water temperature $\left(\mathrm{kPa}^{\circ} \mathrm{C}^{-1}\right)$; $\mathrm{G}$ - variation of heat stored in the body of water $\left(\mathrm{MJ} \cdot \mathrm{m}^{-2}\right.$. day $\left.{ }^{-1}\right)$; ew - saturated pressure of water vapor in the air at the water temperature $(\mathrm{kPa})$. 
(2010 to 2013), while the relative humidity was the lowest from the studied period. In the case of the SisEvapo v2.0 Program (ONS method), which uses data from 1961-1990 Climatological Normal, the mean annual evaporation was strongly underestimated, returning a biased WFP.

Table 3. Mean monthly Camargos HPP reservoir evaporation, obtained by Linacre, Penman, Penman-Monteith and ONS methods (SisEvapo v2.0 Program based on the 1961-1990 Climatological Normal).

\begin{tabular}{lcccc}
\hline \multirow{2}{*}{ Month } & \multicolumn{4}{c}{ Monthly Evaporation (mm) } \\
\cline { 2 - 5 } & Linacre & Penman & $\begin{array}{c}\text { Penman- } \\
\text { Monteith }\end{array}$ & ONS \\
\hline January & 114 & 137 & 133 & 128 \\
February & 111 & 132 & 120 & 141 \\
March & 107 & 116 & 139 & 128 \\
April & 103 & 98 & 116 & 113 \\
May & 94 & 78 & 108 & 92 \\
June & 84 & 63 & 74 & 81 \\
July & 89 & 73 & 81 & 82 \\
August & 117 & 111 & 99 & 97 \\
September & 109 & 115 & 96 & 117 \\
October & 118 & 138 & 117 & 124 \\
November & 106 & 124 & 115 & 138 \\
December & 126 & 151 & 122 & 141 \\
Total & 1279 & 1336 & 1320 & 1382 \\
\hline
\end{tabular}

Table 4. Annual evaporation of Camargos HPP reservoir between 2010 and 2014.

\begin{tabular}{ccccc}
\hline \multirow{2}{*}{ Year } & \multicolumn{4}{c}{ Annual average evaporation (mm) } \\
\cline { 2 - 5 } & Linacre & Penman & $\begin{array}{c}\text { Penman- } \\
\text { Monteith }\end{array}$ & ONS \\
\hline 2010 & 1203 & 1240 & 1226 & \\
2011 & 1211 & 1126 & 1157 & \\
2012 & 1261 & 1373 & 1342 & \\
2013 & 1201 & 1235 & 1225 & \\
2014 & 1519 & 1706 & 1652 & 1382 \\
Average & 1279 & 1336 & 1320 & 136 \\
\hline
\end{tabular}

Table 5. Water footprint (WFP) for the electric energy production in the Camargos HPP between 2010 and 2014.

\begin{tabular}{lcccc}
\hline \multirow{2}{*}{ Month } & \multicolumn{4}{c}{ Water Footprint - WFP $\left(\mathbf{m}^{\mathbf{3}} \cdot \mathbf{G J} \mathbf{H}^{-\mathbf{1}}\right)$} \\
\cline { 2 - 5 } & Linacre & Penman & $\begin{array}{c}\text { Penman- } \\
\text { Monteith }\end{array}$ & ONS \\
\hline January & 95 & 114 & 111 & 107 \\
February & 109 & 129 & 118 & 138 \\
March & 118 & 128 & 153 & 141 \\
April & 115 & 109 & 129 & 126 \\
May & 122 & 102 & 141 & 120 \\
June & 114 & 85 & 100 & 109 \\
July & 116 & 95 & 105 & 107 \\
August & 181 & 172 & 154 & 150 \\
September & 150 & 158 & 132 & 161 \\
October & 141 & 166 & 141 & 149 \\
November & 136 & 159 & 147 & 177 \\
December & 115 & 138 & 112 & 129 \\
Average & 125 & 131 & 129 & 135 \\
\hline
\end{tabular}

\section{Water footprint characterization for Camargos HPP}

Table 5 presents the average water footprint (WFP) results for Camargos HPP estimated based on evaporation obtained by Linacre, Penman, Penman-Monteith and ONS methods.

The average WFP of Camargos HPP, calculated based on the studied methods, for the 2010-2014 period, was $130 \mathrm{~m}^{3} . \mathrm{GJ}^{-1}$, exceeding the values specified in the literature for other facilities in Brazil and worldwide (GERBENS-LEENES; HOEKSTRA; MEER, 2009; MEKONNEN; HOEKSTRA, 2012; BAKKEN et al., 2013).

Gerbens-Leenes, Hoekstra and Meer (2009) estimated the global average water footprint of hydroelectric plants at $22 \mathrm{~m}^{3}$.GJ-1, while Bakken et al. (2013) indicated an average of $18 \mathrm{~m}^{3} . \mathrm{GJ}^{-1}$.

According to Mekonnen and Hoekstra (2012), who studied 35 hydropower plant reservoirs around the world, under different climatic conditions, reservoir size and installed capacity, the global average water footprint for hydroelectric generation was estimated around $68 \mathrm{~m}^{3} \cdot \mathrm{GJ}^{-1}$. This study included eight hydropower plants in Brazil (Sobradinho, Tucurui, Itaipu, São Simão, Marimbondo, Itumbiara, Estreito and Jaguari), whose estimated average WFP was about $84 \mathrm{~m}^{3} \cdot \mathrm{GJ}^{-1}$.

Because of the historical dry season, the average Camargos HPP generation in 2014 was only about 6 MW. Besides that low power, evaporation during 2014, calculated by all methods (except for ONS), was the highest for the period studied and much higher than the normal, as discussed before. Thus, the water footprint estimated for that year $\left(272 \mathrm{~m}^{3} \cdot \mathrm{GJ}^{-1}\right)$ was much higher than for other years evaluated.

Figure 3 illustrates the WFP monthly distribution throughout the year, obtained based on the studied methods. In June, due to lower evaporation rates, WFP was low, reaching the minimum monthly value of $85 \mathrm{~m}^{3} . \mathrm{GJ}^{-1}$, considering the Penman method. Lower values were also observed in January, which is characterized as the period with the highest electric energy generation by Camargos HPP, thus reflecting in a greater water use efficiency. The largest WFP values were obtained for August by Penman, Penman-Monteith and Linacre methods and in November by ONS, corresponding to the months with the lowest energy generation by Camargos HPP.

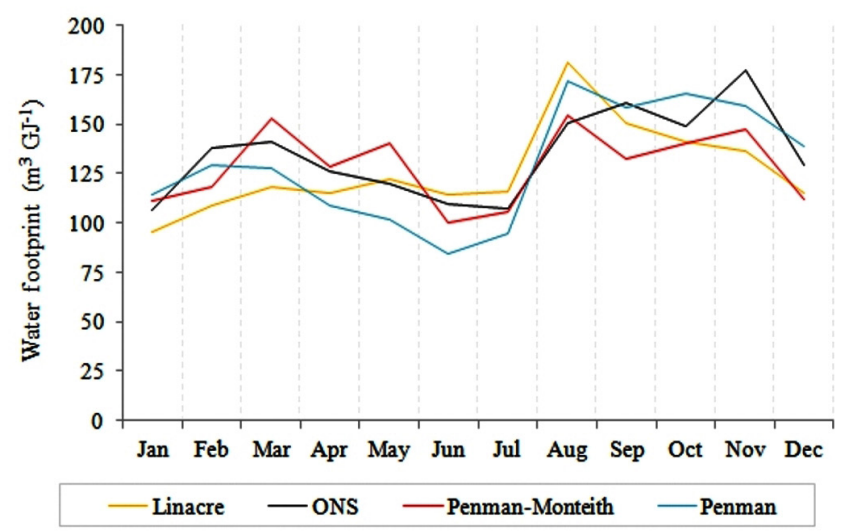

Figure 3. Average WFP for Camargos HPP calculated from the evaporation rates estimated by the Linacre, Penman, PenmanMonteith and ONS methods. 


\section{CONCLUSIONS}

- The temporal distribution of evaporation from Camargos HPP reservoir, by all methods considered in this study, showed the same seasonal pattern, consistent with the meteorological elements behavior that influence this process.

- In terms of annual evaporation during the studied period (2010-2014), the methods indicated an average of $1329 \mathrm{~mm} \cdot \mathrm{yr}^{-1}$. However, the year of 2014 resulted in greater evaporation values due to a severe dry season that has affected the region. The evaporation adopted by the ONS method for Camargos HPP reservoir underestimates it as this method is based on Climatological Normal of INMET and does not able to capture temporal behavior of the weather elements, like was observed for 2014.

- The water footprint calculated for the Camargos HPP was a result of the combination of meteorological elements and the pattern of the electric energy generation during the studied period. Because of the evaporation behavior and the size area of the reservoir, energy generation had a greater weight in the calculation of water footprint.

- The electric energy production by Camargos HPP for the period studied (2010-2014) was low, resulting, by all methods evaluated, in a high water footprint (average of $\left.130 \mathrm{~m}^{3} . \mathrm{GJ}^{-1}\right)$, compared to those values indicated in the literature for other hydroelectric plants in Brazil and even in the world. It was observed that during prolonged dry periods, as in 2014, the water footprint was extremely high $\left(272 \mathrm{~m}^{3} \cdot \mathrm{GJ}^{-1}\right)$, making this plant highly inefficient, from a water use point of view.

\section{ACKNOWLEDGEMENTS}

To CAPES for the scholarship. To CNPq and FAPEMIG for financial support for the development of the project and to CEMIG for providing research data.

\section{REFERENCES}

ANDRIOLO, M. V.; KAVISKI, E. Projeto HG-211: revisão, atualização e aperfeiçoamento do sistema de avaliação líquida dos reservatórios do sistema interligado nacional: SisEvapo v2.0: relatório final. Curitiba: CEHPAR, 2005.

BAKKEN, T. H.; KILLINGTVEIT, A.; ENGELAND, K.; ALFREDSEN, K.; HARBY, A. Water consumption from hydropower plants: review of published estimates and an assessment of the concept. Hydrology and Earth System Sciences, v. 17, p. 3983-4000, 2013.

COElho, C. A. S.; CARDOSO, D. H. F.; FIRPO, M. A. F. Precipitation diagnostics of an exceptionally dry event in São Paulo, Brazil. Theoretical and Applied Climatology, p. 1-16, 2015.

FINEP - FINANCIADORA DE ESTUDOS E PROJETOS. Previsão de afluência a reservatórios hidrelétricos: projeto FAURGS/ FINEP 40.04.0094.00. Brasília, 2007.
GERBENS-LEENES, P. W.; HOEKSTRA, A. Y.; MEER, T. H. $\mathrm{V}$. The water footprint of energy from biomass: a quantitative assessment and consequences of an increasing share of bio-energy in energy supply. Ecological Economics, v. 4, n. 68, p. 1052-1060, 2009.

HOEKSTRA, A. Y.; CHAPAGAIN, A. K.; ALDAYA, M. M.; MEKONNEN, M. M. The water footprint assessment manual: setting the global standard. London: Earthscan, 2011.

LINACRE, E. T. A simple formula for estimating evaporation rates in various climates, using temperature data alone. Agricultural Meteorology, v. 18, p. 409-424, 1977.

MCJANNET, D. L.; WEBSTER, I. T.; STENSON, M. P.; SHERMAN, B. S. Estimating open water evaporation for the Murray-darling basin: a report to the Australian government from the CSIRO MurrayDarling basin sustainable yields project. Melbourne: CSIRO, 2008.

MEKONNEN, M. M.; HOEKSTRA, A. Y. The blue water footprint of electricity from hydropower. Hydrology and Earth System Sciences, v. 16, p. 179-187, 2012.

MELLO, C. R.; NORTON, L. D.; CURI, N.; YANAGI, S. N. M. Sea surface temperature (SST) and rainfall erosivity in the Upper Grande River Basin, Southeast Brazil. Ciência e Agrotecnologia, v. 36, p. 53-59, 2012.

ONS - OPERADOR NACIONAL DO SISTEMA ELÉTRICO. Diretoria de Planejamento Programação da Operação. Evaporações líquidas nas usinas hidrelétricas: ONS RE 3/214/2004. Brasília, 2004.

PENMAN, H. L. Natural evaporation from open water, bare soil and grass. Proceedings of the Royal Society of London. Series A, Mathematical and Physical Sciences, v. 193, n. 1032, p. 120-145, 1948.

VIOLA, M. R.; MELLO, C. R.; BESKOW, S.; NORTON, L. D. Impacts of land-use changes on the hydrology of the grande river basin headwaters, Southeastern Brazil. Water Resources Management, v. 28, p. 1-14, 2014.

VIOLA, M. R.; MELLO, C. R.; CHOU, S. C.; YANAGI, S. N. M.; GOMES, J. L. Assessing climate change impacts on Upper Grande River Basin hydrology, Southeast Brazil. International Journal of Climatology, v. 35, p. 1054-1068, 2015.

\section{Authors contributions}

Eduardo de Oliveira Bueno: PhD student. Preparation of calculation spreadsheets, as pre-defined methodologies; the calculations; analysis and presentation of results. Structuring and text editing.

Carlos Rogério de Mello: Leader. Project design; definition of methodologies; and interpretation of results. Translation and text completion.

Geovane Junqueira Alves: Master student. Installation and maintenance of the meteorological station; collecting, consistency and organization of data. 